\title{
The Application of Intersemiotic Translation Combined with Multimodal Activities in the English as a Foreign Language Classroom
}

\section{A aplicação da tradução intersemiótica combinada a atividades multimodais na sala de aula de inglês como língua estrangeira}

Sinara de Oliveira Branco*

Universidade Federal de Campina Grande

Campina Grande - Paraíba - PB

RESUMO: Este artigo apresenta a análise da aplicação de atividades utilizando filmes e a categoria intersemiótica de tradução como ferramenta de apoio às habilidades de escuta, fala, leitura e escrita. A fundamentação teórica está relacionada à Teoria Funcionalista da Tradução, às Categorias de Tradução, à Teoria de Tradução e Cultura e à Teoria de Tradução e Cinema. Foram elaboradas quatro atividades para a prática da língua inglesa com estudantes iniciantes do Curso de Letras-Inglês da Universidade Federal de Campina Grande (UFCG). As atividades foram baseadas nos filmes Finding Neverland e Alice in Wonderland, de Tim Burton. Foi também aplicado um questionário para averiguar a opinião dos alunos sobre a validade das atividades para o estudo da língua inglesa. Os resultados demonstram que o uso de atividades que envolvam a categoria intersemiótica de tradução e multimodalidade, quando trabalhadas em conjunto com teorias específicas, auxilia no aprendizado da língua inglesa, proporcionando maior participação e interação entre professor e estudantes.

PALAVRAS-CHAVE: Tradução Intersemiótica; Multimodalidade; Ensino de Línguas Estrangeiras; Cinema.

ABSTRACT: This paper presents the analysis of the application of activities using films and the intersemiotic category of translation as a tool for the practice of the abilities of listening, speaking, reading and writing. The theoretical framework is based on the Functionalist Approach of Translation, Translation Categories, the Theory of Translation and Culture, as well as the Theory of Translation and Cinema. Four activities were created to use the English language

*sinarabranco@gmail.com 
with beginner students of the Modern Languages Course (Letras-Inglês) of the Federal University of Campina Grande (UFCG). The activities were created based on the films Finding Neverland and Tim Burton's Alice in Wonderland. A questionnaire was also created to assess the students' opinion concerning the validity of such activities for the study of the English language. Findings have shown that the use of activities involving the intersemiotic category of translation and multimodality, when applied together with specific theories, helps the study of the English language, promoting more participation and interaction between teacher and students.

KEYWORDS: Intersemiotic Translation; Multimodality; Foreign Language Teaching; Cinema.

\section{Introduction}

This paper is based on an undergraduate research project carried out at the Federal University of Campina Grande (UFCG) during the years 2011 and 2012. One undergraduate student was involved in the research, ${ }^{1}$ which had the objective of proposing activities using the translation categories suggested by Jakobson (2000) - intralingual, interlingual and intersemiotic categories of translation. Previously, in the study developed in 2010, it was observed that the frequent use of activities with images, colours, sounds, paintings and other non-verbal elements is paramount for the learning of a foreign language, especially for beginner students. ${ }^{2}$ The researchers came to this conclusion after analysing some books used in English language courses as well as at UFCG. The study showed that there is a need to further investigate the use of the intersemiotic category of translation ${ }^{3}$ involving not only images used in activities in didactic books, but also other media, such as cinema, also focusing on the teaching of English as a foreign language.

The conclusion presented above is reinforced by Zainurrahman (2009), who comments on the fact that in the human mind there are more mechanisms that process visual information than any other human mechanism, such as the processing of the written language. Therefore, students

\footnotetext{
${ }^{1}$ The title of the PIBIC Project was A tradução intersemiótica em sala de aula de linguas estrangeiras [The use of intersemiotic translation in the foreign language classroom].

${ }^{2}$ Such an observation was made during the development of the study $O$ ensino de lingua inglesa através de exercícios de tradução: um estudo de caso [The teaching of the English language through translation activities: a case study].

${ }^{3}$ The term intersemiotic translation refers to the translation of verbal elements by nonverbal elements and vice versa.
} 
seem to be more involved in the learning process when they get in touch with intersemiotic representations of what they study. In other words, discussing images that involve points under study motivates students to interact more, because they feel the need to describe or make comments on the images, presenting their opinion about what they see. This was also observed in class during the application of activities involving intersemiotic translation. Zainurrahman (2009, p.2-3) still emphasizes that visual activities maximize the foreign language development, helping students to memorize language and helping teachers to manage, organize and present their classes. According to the author, videos are also a useful tool, because students see language in use. One profitable way to use videos is preparing activities that make students retell what they have watched, either speaking or writing.

What the author means is that visual aids are important for the memorization of concepts and vocabulary, showing that pictures and videos may be used both in classes with beginner students as well as with more advanced students. Taking such considerations into account, two films were selected Finding Neverland (2004), directed by Marc Forster, and Alice in Wonderland (2010), directed by Tim Burton - considering the relationship of the film themes - the stories of Peter Pan and Alice in Wonderland - with the previous study of the classic novels in other disciplines in order to identify the intersemiotic category of translation in specific scenes of the films, i.e., scenes exploring points involving the characters and the novels, as well as scenes including subtitles of dialogues or simply images and no dialogues. Such scenes were used to create the activities, which had the objective of making the students describe the images, describe the characters' state of mind or explore the dialogues using the images as an extra resource. The activities were applied in an English classroom of beginner students together with a questionnaire that aimed to assess the application of such activities by the students. After the application of activities and the questionnaire, the students' answers were analyzed, taking into account the theoretical framework studied regarding Multimodal Corpora, Foreign Language Teaching, Intersemiotic Translation and Cinema.

Considering the Intersemiotic Category of Translation as a relevant tool for the teaching of a foreign language and taking into account its use for the creation of the activities discussed herein, the general objective of this article is to analyse the use of the intersemiotic category of translation to promote English language teaching at the basic level through activities involving the four skills (listening, speaking, reading and writing). To achieve this aim, two specific 
objectives are presented: i) identify the intersemiotic category of translation in scenes of the films, Finding Neverland and Alice in Wonderland, considering the applicability of such scenes in activities to be used in classes of beginner students, involving the four skills; and ii) investigate what activities best fit the teaching context, favouring the study of English as a foreign language.

\section{Translation and the Functionalist Approach}

According to Nord (1997, p. 28), "there can be no process of 'translation' without a source text (ST). (...) there has to be a certain relationship between the ST and the target text (TT)." However, "the quality and quantity of this relationship are specified by the translation skopos". The skopos, i.e., the purpose, will "provide the criteria for the decision as to which elements of the ST-in-situation can be 'preserved' and which may, or must, be 'adapted' to the target situation". Although the Functionalist Approach highlights the importance of the TT, it does not neglect the importance of the ST and pinpoints its importance for the production of a TT that is accepted by the target readership. In this vein, Nord $(1997$, p. 72$)$ mentions that in the Western culture, two points are particularly expected from a TT: "functionality of the TT but also loyalty towards the ST sender and his intention". The author points out that being 'loyal' in the Functionalist Approach makes reference to the ST author's intention instead of the structure of the ST. Each text must have a different function, but the translator must be loyal to the author's intention, adapting the structure of the TT to a different function (skopos), if this is the case. To have a clear idea of what the ST is about and what the author's intention is, the translator must analyse the ST carefully.

Nord (1997, p. 1) highlights the importance of having "a model of source-text analysis [translation-oriented] which is applicable to all text types and text specimens, and which can be used in any translation task that may arise." The author claims that such a model can provide the translator with the necessary comprehension of the function and features present in the ST, facilitating the translator's general analysis of the ST and guiding him/her more precisely in the translation work. Such a "model should therefore be: (a) general enough to be applicable to any text; and (b) specific enough to take into account as many universal translation problems as possible" (p. 2). In general terms, with the application of such a model, based on functional translation criteria, the translator will be able to choose translation strategies that can be more appropriate for the purpose of a specific translation. According to Nord 
(ibid.), these translation strategies are chosen depending on the intended purpose of a particular translation.

It is difficult to delimit what text is functional in a specific context without considering readership, since "a text can have as many functions as it has recipients" (p. 17). In other words, besides taking into account functional criteria of translation, it is important to consider the function of the text. In this line of thought, it is possible to say that a functional text is characterised by "a combination or 'configuration' of features" (ibid.), which can be constituted by both extratextual (i.e. pragmatic) and intratextual (semantic, syntactic, and stylistic) elements.

Moreover, Nord (ibid.) mentions that "it may seem pointless to consider the possibility of matching one translation with one particular ST, or even offering any criteria for an optimum translation". The author considers such a fact because of the multiplicity of functions and recipients' expectations. Nord (ibid.) goes on to say that "if reception is absolutely dependent on individual conditions [or on the communicative act-in-situation], there will be no chance whatsoever of finding evaluation standards which will take into account every single reception process." This statement sheds light on the discussion of what is a 'good' or a 'bad' translation. This is a subjective discussion which generally sounds pointless and impossible to be answered. Nord (ibid.) argues that in order to overcome this problem of determining 'good' or 'bad' translations, first, it is necessary "to control ST reception by a strict model of analysis that covers all the relevant text features or elements, and, second, to control TT production by stringent 'translating instructions' which clearly define the (prospective) function of the TT" (p. 17-18).

Besides considering the $\mathrm{ST}$ analysis and the target readership, it is also important to consider the means through which the TT will be transmitted. According to Nord (ibid.), the means of transmission affects both the conditions of reception and those of production. The means determines how the information should be presented as regards: (i) level of explicitness, (ii) arrangement of arguments, (iii) choice of sentence organization, (iv) features of cohesion and (v) use of non-verbal elements, such as facial expressions and gestures. By choosing a specific medium, it is possible to illustrate the intratextual factors observing deictic aspects - situational references - which do not have to be verbalized explicitly in face-to-face communication, but rather must be expressed much more clearly in written communication. 


\section{Jakobson's Categories of Translation}

In a globalized era, when the access to languages and cultures is paramount, the idea of translation has broadened in order to provide the needs of scholars, translators and the public in general. Oustnoff (2011) argues that before becoming a field of study for scientists, translation is present in everyday life, since it is a part of language. Oustinoff (2011) goes on to say that it is necessary to understand that translation involves oral and written, verbal and non-verbal, communication.

Jakobson (2000) considers the meaning of any word, phrase or image a linguistic-semiotic factor. Therefore, Jakobson suggests three translation categories involving the diversity of signs and meanings used in communication. The Intralingual Category involves the interpretation of verbal signs by other signs in the same language. This idea refers to synonyms, definitions and circumlocutions, for example. The Interlingual Category involves the interpretation of verbal signs in one language by verbal signs in a different language. Bilingual dictionaries, for example, give meanings of terms from one language in another. The Intersemiotic Category, which is the core interest of this work, involves the interpretation of verbal signs by non-verbal signs and vice-versa, i.e., the interpretation of an image, painting, sound, etc., in a written or oral text, or the interpretation of a song in a film or play.

Regarding the intersemiotic translation, Oustinoff (2011) mentions that its presence in everyday life is so common that it is hard to identify when it happens. Nowadays, translation is understood in a broader sense, because it is present in several contexts. Taking these authors' ideas into account, it is possible to see the use of the intersemiotic category of translation as a creative tool that facilitates the elaboration of activities for application in classes of English as a foreign language. The use of films seems to contribute to the application of translation in such classes, together with the four skills.

\section{Cinema, Translation and Culture}

Cronin (2009) affirms that translation is present in films and in the arts in general, reinforcing the idea that films must be used in teaching, because they can be a good example of the use of translation. This point can be justified by the fact that students seem to feel more motivated to make comments and to interact through the stories and situations presented in film sequences. In his book, Translation goes to the movies, Cronin (2009) shows that the cinema 
is evidence of translation that must be included in teaching as well as in the observation of perspectives of translation.

Cronin (2009) pinpoints cultural characteristics involving films and translation, and mentions that visual evidence is extremely persuasive, making the cinema acquire international acknowledgement from its beginning. Using films while teaching foreign languages helps not only in the contact with foreign languages, but also in presenting cultural aspects, which are an important point to be explored in foreign language classes.

Languages associated with the cinema in general work as a union or intersection of cultural knowledge, making the study of a foreign language more than the knowledge of linguistic signs. Learning a foreign language involves the previous knowledge about the world and about us, about our mother tongue and culture, in order to understand and internalize a foreign language and culture. Following this idea, cinema can be considered relevant to the study of foreign languages, since it is a tool for the sharing of knowledge as well as for the cultural sharing of different peoples. Cronin (2009) and Oustinoff (2011) share the idea of cinema as cultural representation. The use of films in the classroom plays an important role to open doors for the knowledge of other cultures and for the improvement of communication skills when using a foreign language.

\section{Describing the method of investigation and activities}

To apply the activities created for this study, a descriptive and ethnographic study was developed, exploring "characteristics of people and places that cannot be easily described through numbers" (MOREIRA; CALEFFE, 2008, p. 73). In other words, it was necessary to spend time interacting with students and taking part of class to become familiarized with the group. Researchers spent one month observing classes and interacting with the group of students.

Moreira and Caleffe (2008, p. 70) cite Gil (1994) to say that the main objective of descriptive research is to describe a certain population or phenomenon or the relationship among variables. Furthermore, the authors affirm that the importance of descriptive research is based on "the fact that problems can be solved and practices improved by precise observation". The authors also explain that ethnographic research deals with interaction between the researcher and the object of study. Interaction is generated by sharing the researcher's and the participants' experiences in the most natural way possible. 
Ethnographic research describes, analyses and interprets the social life of a group, demanding direct involvement from the researcher in the activities of the group to be investigated (MOREIRA; CALEFFE, 2008, p. 85). The core point of the ethnographic research is that "the procedure and data analysis involve contextualization, in which results are interpreted making reference to the group observed" (p. 86).

The methodology used here is also classified as action-research, because the purpose is to describe how the use of activities involving translation (mainly the intersemiotic category of translation) and films can be applied in the foreign-English-teaching classroom, influencing the development of the English language, showing the need for teachers to be aware of the benefits of the use of translation as a tool to give support to foreign language teaching. For the development of this analysis, the theoretical framework will be revisited, relating translation theories with foreign language teaching, observing how such theories can be applied in the classroom through activities using intersemiotic translation and films.

A selection of scenes of the films Finding Neverland and Alice in Wonderland was made to identify the intersemiotic category of translation in them. The compilation of scenes intends to favour the creation of activities that promote the development of the four skills (listening, speaking, reading and writing) in English. Two scenes of the film Finding Neverland were selected. The first scene takes place in a theatre where Mr. Berry, a famous playwright; Mr. Frohman, the sponsor of Mr. Berry's plays; and some actors are rehearsing and discussing one of the characters' outfits. The second scene takes place at Mr. Berry's summer house, where Sylvia Davies and her four sons are spending some time after Mr. Berry's invitation. One afternoon, they are playing pirate and their play seems so real that in their imagination they feel they are real pirates. The scene was selected and split into two images that show both the realistic and the imaginary view they have of the play.

The theme song of the film Alice in Wonderland, called Alice (Underground), was also selected to be part of the activities. The singer is Avril Lavigne and the choice for this song is justified by its narrative aspect, telling Alice's dilemma and expressing the relationship with Tim Burton's film, due to its dramatic aspect and melancholic rhythm, representing the director's style, providing a link between the story and the film adaptation of Lewis Carroll's novel. The intersemiotic aspect of the film is also present in the song, making the students perceive feelings involved in the plot through the singer's 
interpretation and the lyrics. The image of the Mad Hatter was also selected, representing the changes the character has suffered. These differences were compared to each other and to Tim Burton's version of the Mad Hatter. One of the activities developed presents the present Mad Hatter's image side by side with two other versions: the image from the first version of Lewis Carroll's book and the image from the Disney cartoon, from 1957. Besides the selection of scenes, images and the song, a questionnaire was applied with the students to assess their opinion about the activities and what activities best fit the context of application, according to the students' point of view. After applying the activities, they were analysed by the researchers and comments were made to investigate the implications of the use of such activities on teaching English as a foreign language.

In general, the activities created had the objective of analysing how intersemiotic translation can be used as a tool to help the development of English as a foreign language, in order to contribute to the students' use of the four skills - listening, speaking, reading and writing.

To elaborate the activities, some points were taken into account: i) the use of the intersemiotic translation in each activity, ii) focus on specific objectives involving the four skills, and iii) the focus on creating a number of activities that could possibly be applied within the number of hours available ( 4 hours), leading to four activities, each activity focusing on one or two specific language skills; in some cases, all four skills were involved.

The first activity had the objective of practicing listening, speaking, reading and writing skills, making students reflect on points concerning the story in the film and their previous knowledge of Alice in Wonderland. The activity was divided into two moments: i) the students listened to the song "Alice (Underground)", and then received the lyrics to be read while they listened to the song a second time. After listening and reading the song, the students discussed some questions about it. The questions involved elements such as rhythm, melody, and tone of voice, and the students had to interpret how such elements influenced or reflected the atmosphere in the film. The activity helped students perceive non-verbal elements as an important factor for the construction of the story as well as for the verbal elements, leading them to interpret intersemiotic elements into verbal elements; ii) the students read two reviews of the song posted on blogs, presenting opinions about the song and the singer, and had to analyse if the comments were positive or negative. The students read the comments and highlighted words that proved their 
opinions. After, the students gave their personal opinions, and wrote their comments.

The second activity was still about Alice in Wonderland, and had the objective of comparing the character Mad Hatter in three different versions of the story: the first edition of Lewis Carroll's book, "Alice in Wonderland", the Walt Disney cartoon from 1957 and Tim Burton's version, narrating Alice's return to Wonderland when she is 18 . The comparison made students reflect on the possible reasons for the construction of Tim Burton's Mad Hatter, identifying semiotic elements that express psychological characteristics and feelings. The students had to analyse the three images and discuss the character's construction by listing the characteristics that had remained from the first to the third image, as well as what had changed, trying to find reasons why the changes were applied. Interpreting the images and interpreting meanings made students speak in English most of the time in order to discuss and present their arguments.

The third activity involved the film Finding Neverland, and had the objective of developing listening and reading skills, together with textual interpretation. The students had to listen to a dialogue and read it. Next, they had to transform the verbal elements into drawings, using intersemiotic elements to make the translation of a verbal text into a non-verbal image. The dialogue used in the activity was a conversation between two characters during the rehearsal of the play Peter Pan. The playwright and the sponsor were watching the rehearsal and giving opinions. The students had to read the dialogue after listening to it, contextualizing the scenario. Without seeing the scene, the students had to draw the scene as they imagined it. In this case, the students worked with their imagination, along with the listening and reading skills.

The fourth and last activity had two images taken from the film Finding Neverland, and had the objective of developing the writing skill. In this case, the students had to describe the image in order to write a text about such images, creating a story for the images. The story the students were to write was a dialogue involving the characters playing as pirates on a ship.

\subsection{Participants and context of investigation}

The students selected were a group of beginner students from the Modern Languages Course (Letras-Inglês) of the Federal University of Campina Grande (UFCG), during semester 2012.1. The activities were 
created in English during the development of the study and applied in English in the discipline Lingua Inglesa I [English I]. On April 27, 2012, the teacher authorized the application of the activities and questionnaire during four onehour classes. The group consisted of 21 students, but only 13 students were present that day. The students' age varied from 20 to 23 years of age, ${ }^{4}$ of which most were real beginners in the study of English as a foreign language; five students were considered intermediate level students of English. The work started with a brief conversation about the two stories Alice in Wonderland and Peter Pan, which were adapted to the selected films and, consequently, generated the activities. To take part in this research, the students signed an informed consent form (agreeing to their participation as volunteers and guaranteeing their privacy).

\subsection{Report of the application of activities}

Table 1 shows the questions used for the students to give their opinions about the song as a narrative of Alice's story in Wonderland. The second question, for example, made students remember physical characteristics and moments of the story to describe Alice; such as the colour of her hair (blonde) and the colour of her dress (blue). They described the place where the story happens and the fact that Alice was with her sister when she saw the white rabbit. They also described Alice falling into the hole, ending up in Wonderland. The students confirmed that the music describes Alice's story. In the fourth question, the students answered that some feelings expressed in the song were: surprise, fear, courage and being lost. They related the melody of the song and the singer's performance with the narrative, describing Alice as wonderful and brave, but also scared, because she was lost in a place totally different from her homeland. The students were also asked to relate the idea in the song and in the film with any situation they had faced in their own lives. A group of students told a story of a day they took the wrong bus, ending up in a wrong place. They told that they felt lost and scared, because it was almost dark, but that they pretended everything was all right so as not to call the attention of strangers. Other students told that they had passed through hard moments when they did Vestibular, i.e., the entrance examination test for entering the university in Brazil, and had to choose what to study at the university.

${ }^{4}$ The information regarding the students' ages was taken from the questionnaires. 


\section{TABLE 1}

Activity 1.1

- What is the song about?

- Who's Alice?

- Do you know Alice's story? If yes, does the song describe it well?

- What kinds of feelings are described in this text? What helps you to understand these feelings? Are they related to the situation of Alice in the original story?

- Have you been in a situation like that? When? Where?

Source: ARAÚJO, A. A. de. A tradução intersemiótica em sala de aula de línguas estrangeiras. PIBIC/CNPq. Campina Grande, 2012.

As already mentioned previously, the students had to make comments about the song in Activity 1.2, as well as answer some questions (Table 2) regarding the song and the comments about it. First, the answers were given orally; the first three questions were answered in groups, and the last one, individually and written. Up to that moment the students responded well to the objectives and expectations of the activities and participated actively in the discussions. During the discussion, some students spoke English, while some others used their mother tongue when necessary (sometimes as interlingual translation and sometimes the use of the mother tongue itself). When asked to write their own comments, relating them not only to the film, but also to Lewis Carroll's story, four students answered the activity in English, while eight students answered it in Portuguese.

\section{TABLE 2}

\section{Activity 1.2}

- What do these comments talk about? Are they positive or negative?

- Whith which do you agree with? Why?

- What are the main compliments or critics made to the song/singer?

- Write your own comment about the song, relating it with the original "Alice in Wonderland" story by Lewis Carrol and your previous knowledge about the singer. Take a side.

Source: ARAÚJO, A.A. de. A tradução intersemiótica em sala de aula de línguas estrangeiras. PIBIC/CNPq. Campina Grande, 2012

Activity 2 presented the images of the Mad Hatter for them to list the similarities and differences in them. The activity was answered in groups and discussed in class. When they observed the images (Table 3), the students said that the Mad Hatter in the three images looked crazy. They also said that the character called the attention of both the readers and the audience, which was appealing. The students noticed that what the images had in common was the hat and the bow tie, concluding that these are important elements in the construction of the narrative as well as for the character's construction and representation. 
The students compared one image to the other and concluded that the representation varied according to the audience and to the year it was created. The first image was more traditional, in black and white, and it was directed to children; the second image looked crazy or funny, and was directed to the Walt Disney audience and was not scary. The last image was modern and fashionable, passing through a long transformation representing a Mad Hatter directed to an adult audience. In the students' opinion, the third Mad Hatter was the one that best represented the character's personality, because they felt disturbed by it, since it passed on the idea of 'inner-craziness', which was perceived in the colours and accessories used by the character. The students considered the third image intense and mysterious, because they were not able to say whether the character was good (hero) or evil (villain). During this activity, the students participated more than expected, i.e., as they were beginner students, less interaction in English was expected, but they gave their opinions in English, appearing to perceive the characteristics that were not even expected or directed in the creation of the activity.

\section{TABLE 3 \\ Activity 2}

Source: https://www.google.com.br/search?q=imagem+do+chapeleiro+maluco+ de+Lewi+carroll\&biweiro-maluco.html

http://blogladob.com.br/geral/deputado-psico/attachment/chapeleiro-louco/ and https://www.google.com.br/search?q=chapeleiro+maluco+tim+burton\&biw.

Activity 3 presented a dialogue (Table 4) from the film Finding Neverland, and the students had to transform the verbal representation into a non-verbal representation, i.e., to draw a picture of the dialogue.

TABLE 4

Activity 3

J. M. Barrie: [watches Nana-The dog crawl across the stage and bump head-first into one of the beds] Nanny? Nanny? Um, first you get
the pajamas, then you make the bed.
Nana The Dog: With my paws?
I. M. Barrie: You make the bed with your paws; the pajamas you get with your teeth. Because in fact, being a dog, you haven't
any proper digits, have you?
Nana The Dog: Well I don't have any teeth either! I mean I can't see, I can't breathe, all I've got is this rubbery snout.
J. M. Barrie: [looks back at Frohman] Can we get him some teeth?
Charles Frohman: He can have mine.

Source: FORSTER, Marc. Finding Neverland [movie]. Production by David Magee, Directed by Marc Forster, United States, Miramax, 2004. DVD, 106 min. 
The last activity, Activity 4, did not seem to fully achieve the expected aim, because the aim of the activity was for the students to write their responses in English. The students had to observe two scenes of one of the films and write a story for it. However, only one student answered it in English, while the other students did it in Portuguese.

\subsection{Questionnaire Report}

The questionnaire was applied after the activities, which was developed in Portuguese, as can be seen below. All 13 students answered it. The four questions were related to the students' opinions about the activities and their effectiveness as regards the study of English as a foreign language. The students had to answer the questions taking into account points concerning their present condition, as students, and their future condition, as foreign language teachers.

\section{TABLE 5}

Questionnaire

Questionário para Aplicação após as atividades

Idade:

Questionário

1. Você acredita que atividades desse tipo são válidas para aplicação em contexto de sala de aula de lingua inglesa:

a) Em escola de linguas?

b) Em escola regular pública?

c) Em escola regular privada?

d) Em nivel universitário?

e) Não são válidas?

f) Comente:

2. Você é a favor do uso de midias variadas em sala de aula (filmes, slides, músicas, imagens etc) para $o$ ensino de linguas?

Sim

Não

Comente:

3. Você acredita que esse tipo de atividade auxilia no uso das quatro habilidades (escuta, fala, leitura, escrita)?

Sim

Não

Comente:

4. Qual das atividades você considerou de melhor aplicaçâo/resultado? Você utilizaria atividades assim? 


\section{Data Analysis}

The application of Activity 1.1 achieved its proposed aims, since the students succeeded in comparing the song with the book Alice in Wonderland, taking into account semiotic elements in the song that helped the students to interpret the content in the story. The students came to the conclusion that the melody of the song, as well as the way the singer sang it, was a representation of Alice's drama described in the story, both in Lewis Carroll's book and in Burton's film.

Although the students still have a beginner level of English, they felt free to discuss the activity and share their experiences in English. One of the students, for example, answered that the activities were useful, for the fact that they could use of the four skills, motivating debate in the classroom. The student's point of view corroborates with Zainurrahman's (2009) idea that activities involving images and sounds are effective in the beginner level of learning foreign languages, because oral and non-verbal activities do not seem to be intimidating, opening space to conversation between teacher and students.

However, Activity 1.2 did not seem to be as successful when applied. On one hand, the initial questions made the students answer orally, discussing their opinions and achieving the aims. On the other hand, in the fourth question they had to write a text. Four of the twelve students in the class answered the question in English, that is, only $30.76 \%$ of the students achieved the activity's original aim, while $61.53 \%$ did not succeed in the producing what was asked in English, answering the question in Portuguese. The most probable reasons for the students to have answered the question in Portuguese are: i) the instruction of the activity did not mark that the question should be answered in English; ii) the researcher did not emphasize that the answer should be given in English; and iii) the students were still at the beginner level of learning English and were unable to write properly in English, not including the four students who answered activity in English. 


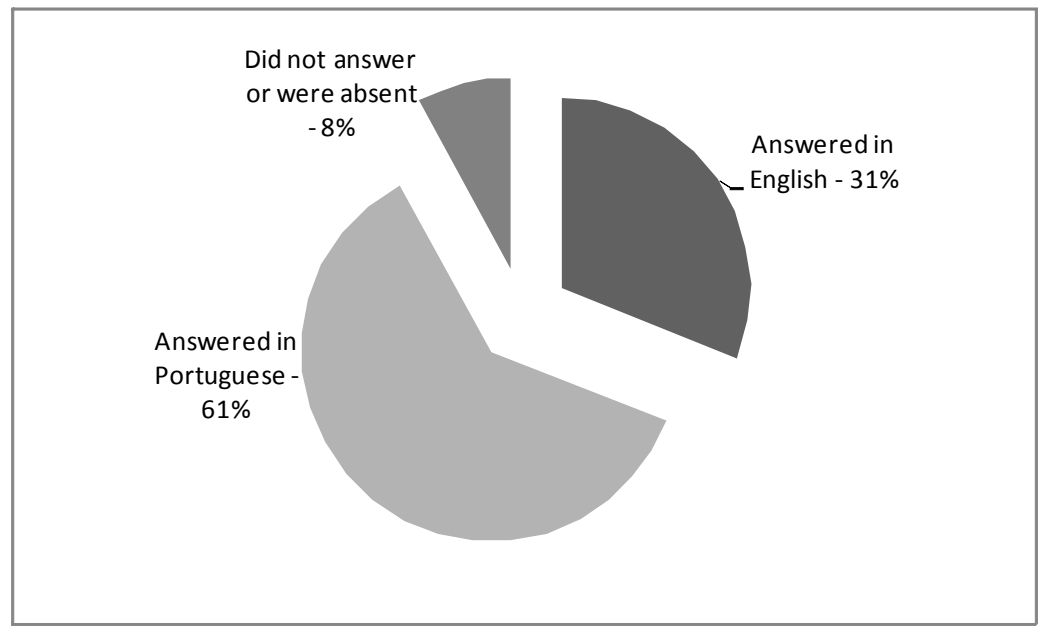

FIGURE 1 - Number of students who answered Activity 2

Source: ARAÚJO, A. A. de. A tradução intersemiótica em sala de aula de línguas estrangeiras. PIBIC/CNPq. Campina Grande, 2012.

The application of Activity 2 was successful and the students showed interest in taking part in it. The semiotic elements constructing the Mad Hatter were discussed with enthusiasm and some students mentioned that this was their favourite activity, due to the interaction it brought to class in terms of student-professor as well as student-student interaction. Such interaction was confirmed by the use of the four skills during the application of Activity 2, helping in socialization and communication, with more freedom of the use of language, with almost no tension. It was also noticed that cultural factors were present in class as well. Zainurrahman (2009) cites Meier (2002) to explain that because we are all visual beings, activities using images are welcome to develop different skills and knowledge - including cultural factors - because the brain transforms visual information into codes easier than any other kind of information.

Activity 3 used intersemiotic translation to make the transposition of verbal signs into nonverbal signs. The application of this activity was also successful, with the students showing confidence in reading the text in English and discussing the points in the text afterwards. After reading the text, the students drew the story, presenting elements that formed the scenario described in the written text, representing such a scenario through intersemiotic translation. Observing the image created by one of the students (Picture 1), it is possible to identify that the students understood the idea, represented by 
some elements in the scenario described in the text, and s/he reproduced such elements in the drawing: the actor dressed as a dog, for example, representing the character Nana-The Dog. The students have also succeeded in presenting the scenario of the play in the story, by drawing the stage, lights and furniture of the bedroom where the play took place. The students also drew the aisle and row of seats of the theatre where the audience watched the play, which was the place where the sponsor of the play and the playwright were watching the rehearsal. This case has reinforced Jakobson's (2000) point of view that only creative transposition is possible. The students translated the text through their comprehension of the verbal language, using their creativity, representing the story through the use of non-verbal language, i.e., intersemiotic translation.

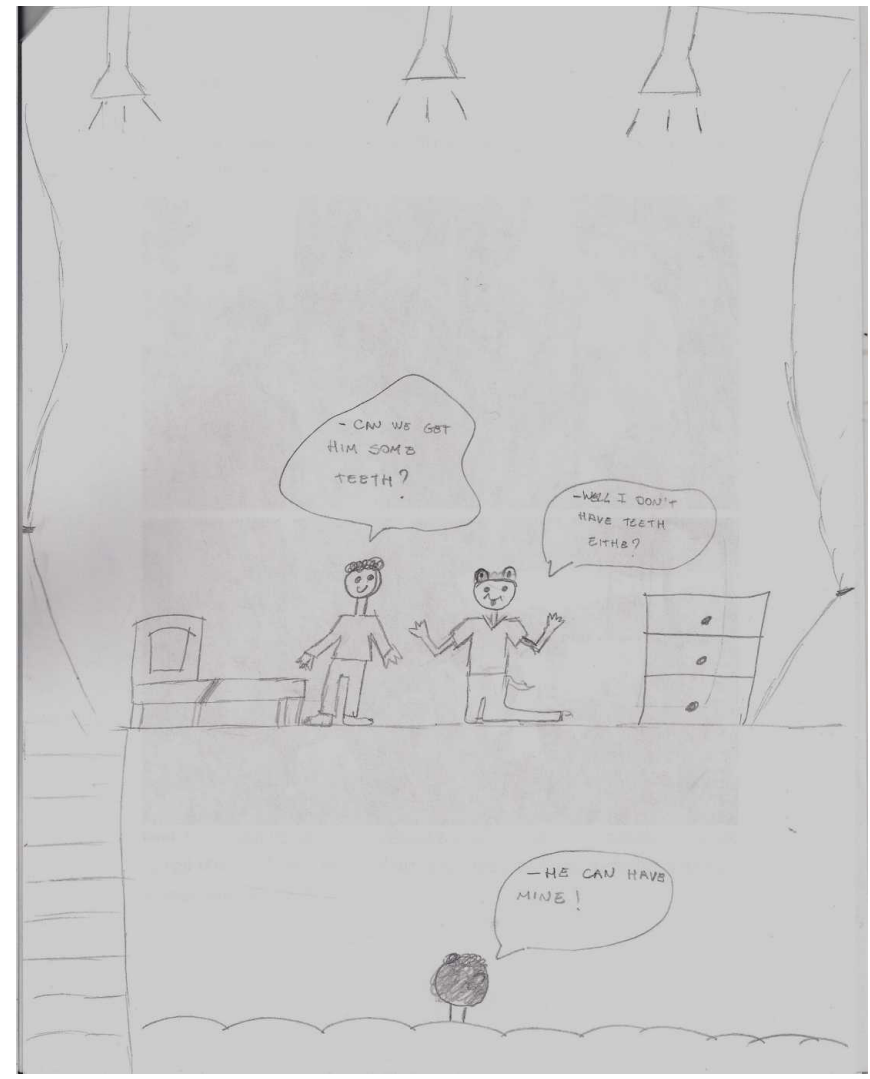

PICTURE 1 - Student's 3 drawing.

Source: ARAÚJO, A. A. de. A tradução intersemiótica em sala de aula de línguas estrangeiras. PIBIC/CNPq. Campina Grande, 2012. 
The last activity, however, did not achieve all of the expected aims. Most students (84\%) wrote the text in Portuguese rather than in English. One student wrote the text in English and another student started the activity in English but did not finish it. To answer the activity, the students made use of the intersemiotic translation category, in which they wrote their texts based on pictures, but they did not write the texts in English, using their mother tongue, not taking advantage of the moment to practice their writing skills in English. The reason for this is not certain, but some of the hypothesis are that: i) the wording of the activity was not clear about the language to be used to answer the question, causing a possible confusion for them to answer, making them revert to the easiest way to elaborate their answers, opting for their mother tongue; ii) the researcher may not have emphasized that the activity should be answered in English; iii) the activity was handed-out before the questionnaire and it was pointed out that the questionnaire should be answered in Portuguese, probably generating the confusion; iv) the students were at the beginner level of studying English, so their writing skills still had not been fully explored, except for some students who had more knowledge of the English language and of writing, but who were considered false beginners. Next, Picture 2 is presented with the participation of students in class during Activity 4.

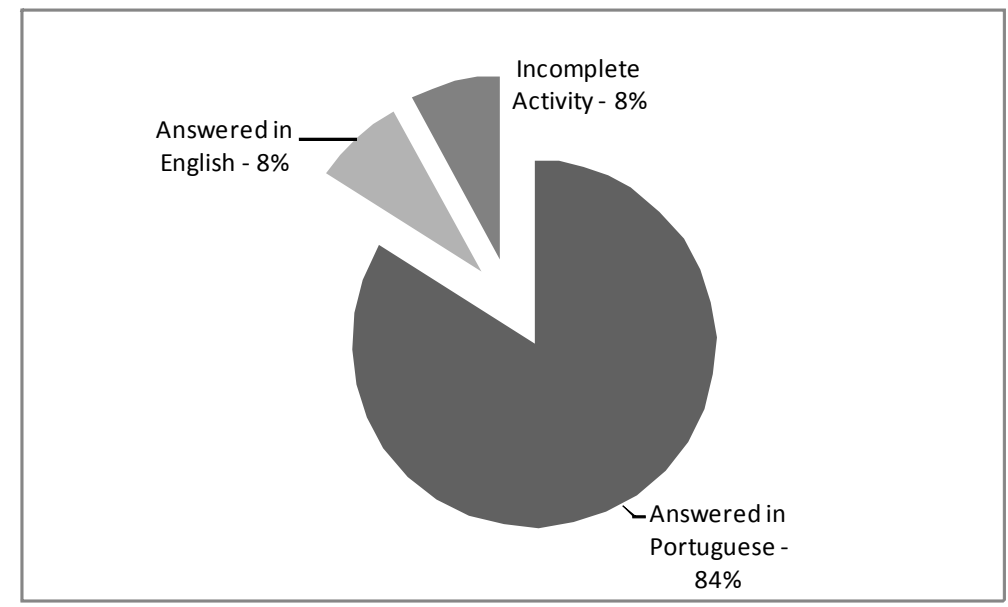

FIGURE 2 - Number of students who did Activity 4

Source: ARAÚJO, A. A. de. A tradução intersemiótica em sala de aula de línguas estrangeiras. PIBIC/CNPq. Campina Grande, 2012. 


\section{Conclusion}

According to Oustinoff (2011, p. 130), translation is a linguistic operation applied "not to previously established units, but to differential units, whose particularity is to be indefinitely susceptible of being seen as smaller units". The author means that when translating from one language into another, the result is "almost the same thing", and the author explains that these units are valuable for their differences in the language system. Because of this, words, sentences, paragraphs, texts or any other translation category (intralingual, interlingual or intersemiotic) in any other language will never mean the exact same thing. Linguistic units as well as intersemiotic translation have meanings that differ, depending on several factors: language, place, time and culture, among others. This idea makes languages a complex maze that renders the translator's work not only a decodification of signs from one language to the other, but also a process of denotation of sense. The author goes on to say that translation is the mediator of diversity among languages and cultures. This idea also brings us to the context of foreign language teaching, where teachers and students are constantly in the frontier of languages and cultures, learning to negotiate in a way that is quite similar to translation.

Furthermore, Cronin (2009) says that in cinema people appear to have similar characteristics to those in films, depending on factors like their culture, social status, time, and education, making them interpret/translate films and characters in several different ways. Taking this into account, translation is integrated into the students' knowledge and is used as a tool to help them use the four skills in English. The activities presented herein, associated with the intersemiotic category of translation, also used the films Alice in Wonderland and Finding Neverland to show that it is possible to use translation in foreign language classrooms, influencing learning in a positive way.

Although some teachers believe translation can be used positively in foreign language contexts, they have no training in how to use it. For this reason, this study had the objective of presenting suggestions of activities involving the intersemiotic category of translation, tracing specific objectives for each activity. The findings show that activities working with speaking and oral comprehension were more successful with beginners, providing more participation and involvement. Activities dealing with writing skills were not as successful as hoped due to the fact that beginner students have not yet reached the point of writing texts in a foreign language. This kind of activity also provided more interaction between the students and the teacher. Moreover, it made the students more comfortable to use English without the fear of making mistakes. 


\section{Acknowledgment}

The authors wish to thank $\mathrm{CNPq}$ for sponsoring this project.

\section{Bibliographical References}

ARAÚJO, A. A. de. A tradução intersemiótica em sala de aula de línguas estrangeiras. PIBIC/CNPq. Campina Grande: EDUFCG, 2012, p. 1-20.

BURTON, Tim. Alice in wonderland. [filme]. Produção de Linda Woolverton, direção de Tim Burton, Estados Unidos, Disney, 2010, DVD, 108 min.

CARDOSO, João Batista. Olhares semióticos sobre a comunicação visual: os estudos dos signos visuais na publicidade. In: Revista Fronteira. V.10. N. 3. UNISINOS: São Leopoldo, 2008, p.183 - 192.

CARROLL, Lewis. As aventuras de Alice no pais das maravilhas. Trad. e org. Sebastião Uchôa Leite. São Paulo: Summus, 1980.

CARROLL, Lewis. Alice através do espelho. Trad. e org. Sebastião Uchôa Leite. São Paulo: Summus, 1980.

CINTAS, Jorge Díaz; REMAEL, Aline. Audiovisual translation: Subtitling Translation Practices Explained. United Kingdom: St. Jerome, 2010.

CRONIN, Michael. Translation goes to the movies. New York: Routledge, 2009. FORSTER, Marc. Finding Neverland. [filme]. Produção de David Magee, direção de Marc Forster, Estados Unidos, Miramax, 2004. DVD, 106 min.

JAKOBSON, Roman. On linguistic Aspects of Translation. In: Venuti, Lawrence (ed.). The Translation Studies Reader. London: Routledge, 2000. p. 113-118.

NORD, Christiane. Translating as a purposeful activity. Manchester: St. Jerome. 1997.

OUSTNOFF, Michaël. Tradução: História, teorias e métodos. Trad. Marcos Marcionilo. São Paulo: Parábola, 2011.

SANTAELLA, Lúcia. O que é Semiótica. São Paulo: Brasiliense, 2005.

ZAINURRAHMAN, Sehan. Visual Learner and Second Language Acquisition. Available at <>. Accessed October 10, 2011.

Recebido em 28/07/2013. Aprovado em 24/01/2014. 